\title{
SPECTROPHOTOMETRIC QUANTIFICATION OF NITRITE AND NITRATE IN CURED PROCESSED MEAT
}

\author{
Elgazzar, M. M. M.I. ${ }^{*}$ Al-Awamry, Z. K.M. ${ }^{* *}$; Marouf, H. A. M. ${ }^{* * *}$ and Khalil, N. H. M. ${ }^{* * *}$ \\ *Department of Food Hygiene and Control, Faculty of Veterinary Medicine, Mansoura University. \\ ** Regional Center for Food and Feed, Agricultural Research Center. \\ *** Food Inspection Laboratory, Animal Health Research Institute.
}

\begin{abstract}
A total of 115 samples of different cured meat products - locally processed and imported ones - were purchased from various groceries and supermarkets in Egypt then analyzed for their contents of both nitrite and nitrate by the aid of spectrophotometer and expressed as $\mathrm{mg} / \mathrm{kg}(\mathrm{ppm})$. The surveyed samples consisted of 25 corned beef ( 9 locally processed plus 16 imported ones), 20 locally processed beef sausage, 15 locally processed patirma, 10 locally processed beef luncheon, 5 imported canned beef luncheon, 20 canned chicken sausage (8 locally processed and 12 imported ones), 10 imported canned chicken luncheon, in addition to 10 locally processed chicken luncheon samples.

Spectrophotometric analyses quantified the range (minimum - maximum) \&mean $\pm S$.E. levels of nitrite in the tissues of locally processed and imported corned beef samples as $4.35-43 \& 14.59 \pm 4.13 \mathrm{mg} / \mathrm{kg}$ and $4.07-78.37 \& 38.94 \pm 6.98$ $\mathrm{mg} / \mathrm{kg}$, respectively, while similar findings for the nitrate were $13.91-40.58 \& 22.8 \pm 2.64 \mathrm{mg} / \mathrm{kg}$ and $12.32-102.5 \&$ $43.88 \pm 6.62 \mathrm{mg} / \mathrm{kg}$ in the same samples, consequently, the sum of both nitrite and nitrate residues were calculated as $23.91-62.2 \& 37.39 \pm 4.5 \mathrm{mg} / \mathrm{kg}$ in locally processed corned beef besides $30.77-141.9 \& 82.82 \pm 9.2 \mathrm{mg} / \mathrm{kg}$ in imported corned beef samples, consecutively.

The aforementioned analytical technique exhibited the minima, maxima, and mean \pm S.E. values of nitrite 6.65, 82, $28.72 \pm 4.34 \mathrm{mg} / \mathrm{kg}$; of nitrate 8.93, 113.01, and $40.6 \pm 5.94 \mathrm{mg} / \mathrm{kg}$; of sum nitrite and nitrate 16.49, 138.7, and 69.33 \pm $7.92 \mathrm{mg} / \mathrm{kg}$, respectively, in the tissues of locally processed beef sausage. While, those findings were 2.03, 69, and $22.35 \pm 4.96 \mathrm{mg} / \mathrm{kg}$ for nitrite; $0.76,114.25$, and $54 \pm 10.42 \mathrm{mg} / \mathrm{kg}$ for nitrate; as well as $18.99,142.71$, and $76.35 \pm 10.06$ $\mathrm{mg} / \mathrm{kg}$ for sum nitrite and nitrate, successfully in the samples of locally processed pastirma.

The lowest levels of nitrite, nitrate, and sum nitrite and nitrate in the analyzed tissues of both locally processed beef luncheon and imported canned beef luncheon samples were $5.22 \& 36.73,1.99 \& 2.99$, and 18.99 \& $63.29 \mathrm{mg} / \mathrm{kg}$; whereas the highest amounts of such residues were $75.5 \& 75.78,74.7 \& 59.56$, and $131.7 \& 96.29 \mathrm{mg} / \mathrm{kg}$; meanwhile the mean levels $\pm S$.E. of these findings were $30.63 \pm 8.28 \& 59.22 \pm 8.32,32.81 \pm 6.4 \& 21.78 \pm 11.16$, and $63.43 \pm 12.46 \&$ $81 \pm 6.81 \mathrm{mg} / \mathrm{kg}$ in the same samples, successfully.

Tissues of locally processed canned chicken sausage revealed nitrite nitrate, and sum nitrite/nitrate by levels ranged from $7.46-47.08,7.5-44.8$, and $22.06-91.88 \mathrm{mg} / \mathrm{kg}$ with mean \pm S.E. values $27.54 \pm 4.54,16.22 \pm 4.6$, and $43.77 \pm$ $7.96 \mathrm{mg} / \mathrm{kg}$, respectively. While, those findings in surveyed samples of imported canned chicken sausage were $18.46-$ $64.11,2.65-93.78,43.51-132.08$ with mean \pm S.E. values $39.21 \pm 3.61,29.07 \pm 7.36$, and $68.28 \pm 7.07 \mathrm{mg} / \mathrm{kg}$, consecutively.

The mean \pm S.E. levels and ranges (minimum-maximum) of the investigated analytes in the samples of imported canned chicken luncheon were found $45.86 \pm 9.37$ and $21.69-99.52 \mathrm{mg} / \mathrm{kg}$ for nitrite, $49.55 \pm 14.55$ and $12.65-149.76$ $\mathrm{mg} / \mathrm{kg}$ for nitrate, in addition to $95.43 \pm 16.03$ and $46.59-198.36 \mathrm{mg} / \mathrm{kg}$ for sum nitrite/nitrate, respectively. Meanwhile, similar findings in the tissues of locally processed chicken luncheon were $35.96 \pm 5.55$ and $11.21-58.4 \mathrm{mg} / \mathrm{kg}$ for nitrite, $37.92 \pm 9.05$ and $1.06-99.81$ for nitrate, as well as $73.88 \pm 6.94$ and $47.36-120.98 \mathrm{mg} / \mathrm{kg}$ for sum nitrite/nitrate, successfully.

An overviewing the obtained results, none of surveyed samples of cured meat products possessed nitrite or nitrate level more than their limits (150\& $250 \mathrm{mg} / \mathrm{kg}$, respectively). Also, public health significance of nitrite and nitrate in cured meat products - marketed in Egypt - as well as the conclusion and recommendations of the present study were also mentioned.
\end{abstract}

\section{INTRODUCTION}

Processed meat and poultry are popular and extremely perishable food. Nitrites and nitrates are used in meat curing because they stabilize attractive red meat color, retard some spoilage and food poisoning anaerobic microorganisms, lateness the development of oxidative rancidity, and share to flavor development (Jiménez-Colmenero and Solana, 2009). Nitrites/nitrates control the growth of spores, particularly from Clostridium botulinum. These spores are a real concern in the meat industry; in order to they can survive 
normal heat processing. Under the suitable conditions, they can produce vegetative cells, which can give a lethal toxin. Nitrates undergo a chemical reaction and are reduced to nitrites. Then, nitrites react with meat protein (myoglobin), and are converted to nitrosomyoglobin (bright red). When exposed to the heat of cooking, nitrosomyoglobin is converted to nitrosohemochrome (pink pigment) (Hyytia et al., 1997). Control and legislation of the adding of preservatives is essential both to assure their effectiveness and because in unsuitable amounts and conditions these meat additives can have adverse health hazards. The present study was planned for quantitative estimation of both nitrite and nitrate levels in such marketable products; either locally processed or imported ones.

\section{MATERIALS AND METHODS}

\section{(A) Collection and preparation of the samples:}

A total 115 samples of locally processed $\&$ imported cured beef and chicken productsconsisted of 25 canned beef ( $9 \& 16), 20$ beef sausage (20\&0), 15 pastirma (dried beef) (15\&0), 10 beef luncheon (10\&0), 5 canned beef luncheon $(0 \& 5)$ besides 20 canned chicken sausage (8\&12) and 10 samples every of canned chicken luncheon $(0 \& 10)$ and chicken luncheon (10\&0), respectivelypurchased from different markets in several Egyptian provinces, then individually packed in a clean polyethylene bags, marked and transferred to the laboratory of Regional Center for Food and Feed /Agricultural Research Center , Cairo/ Egypt wherein they were analyzed for their contents of nitrite and nitrate by the aid of spectrophotometer according to Sen and Donaldson (1978).

Each of the aforementioned samples was represented by $10 \mathrm{~g}$ homogenized with $40 \mathrm{ml}$ distilled water by using a blender. The volume of the resultant homogenate was completed to $500 \mathrm{ml}$ after adding distilled water. The obtained diluted homogenate was placed in hot - air oven at $90-95^{\circ} \mathrm{C} / 20 \mathrm{~min}$ then filtered through $24 \mathrm{~cm}$ - filter paper (whatman, No.1).The filtered and diluted homogenate for every sample - was submitted for quantification of their nitrite and nitrate contents.

\section{(B) Quantification of nitrite levels in the samples:}

Twenty milliliters from the filtered and diluted homogenate - from each sample - was placed in $50 \mathrm{ml}$ volumetric flask and adding $2.5 \mathrm{ml}$ of sulphanilamide ( $\mathrm{p}$ - aminobenzene sulfonamide) reagent were added followed by $2.5 \mathrm{ml}$ of NED reagent $(\mathrm{N}-(1$ - naphltyl ) ethylene - diamine dihydrochloride ) after 5 minutes then completed to $50 \mathrm{ml}$ with distilled water and left for 15 minutes in the dark. Then was placed in cuvette $(5 \mathrm{ml})$ and was detected spectrophotometrically at $540 \mathrm{~nm}$. The purple color - appeared as a result of Griess reaction (diazo compound formation) against blank of $45 \mathrm{~mL}$ water and $2.5 \mathrm{~mL}$ of sulphanilamide reagent and $2.5 \mathrm{~mL}$ of NED reagent. Residual nitrite level was determined by comparison with the prepared standard curve.

Nitrite content expressed as $\mathrm{NaNo}_{2}=$

$$
\frac{\mathrm{CX} 25000}{\mathrm{MXV}}
$$

$\mathbf{C}=$ concentration of sodium nitrite in $\mathrm{mg} / \mathrm{L}$ read from calibration curve that corresponds with the absorbance of the solution prepared from the sample.

$\mathbf{M}=$ mass in grams of sample taken.

$\mathbf{V}=$ volume in milliliters of aliquot portion of filtrate taken for test. 
(C) Quantification of nitrate levels in the samples:

Nitrate is reduced to nitrite in the presence of cadmium granules - packed in a glass column (Wood et al., 1967). The obtained nitrite level for each sample was determined spectrophotometrically - as described before. The higher quantity than before for each sample was transformed into nitrate quantity by multiplying by a factor of 1.23 .

Statistical analysis: The values given in each product were the mean value of three replicates.

Table (1): Nitrite and nitrate contents in cured meat products ( $\mathrm{n}=115$ for all samples)

\begin{tabular}{|c|c|c|c|c|c|c|c|c|c|}
\hline \multirow{2}{*}{$\begin{array}{l}\text { Types of analysed meat } \\
\text { products and their } \\
\text { samples' numbers (n) }\end{array}$} & \multicolumn{3}{|c|}{$\begin{array}{l}\text { Nitrite levels } \\
\text { mg/kg (ppm) }\end{array}$} & \multicolumn{3}{|c|}{$\begin{array}{l}\text { Nitrate levels } \\
\text { mg/kg (ppm) }\end{array}$} & \multicolumn{3}{|c|}{$\begin{array}{c}\text { Sum of nitrite and nitrate } \\
\text { levels } \\
\mathrm{mg} / \mathrm{kg}(\mathrm{ppm})\end{array}$} \\
\hline & Min. & Max. & Mean \pm S.E. & Min. & Max. & Mean \pm S.E. & Min. & Max. & Mean \pm S.E. \\
\hline $\begin{array}{c}\text { Locally processed corned } \\
\text { beef (9) }\end{array}$ & 4.35 & 43 & $14.59 \pm 4.13$ & 13.91 & 40.58 & $22.8 \pm 2.64$ & 23.91 & 62.2 & $37.39 \pm 4.5$ \\
\hline Imported corned beef $(16)$ & 4.07 & 78.37 & $38.94 \pm 6.98$ & 12.32 & 102.5 & $43.88 \pm 6.62$ & 30.77 & 141.9 & $82.82 \pm 9.2$ \\
\hline $\begin{array}{c}\text { Locally processed beef } \\
\text { sausage (20) }\end{array}$ & 6.65 & 82 & $28.72 \pm 4.34$ & 8.93 & 113.01 & $40.6 \pm 5.94$ & 16.49 & 138.7 & $69.33 \pm 7.92$ \\
\hline $\begin{array}{l}\text { Locally processed pastirma } \\
\text { (15) }\end{array}$ & 2.03 & 69 & $22.35 \pm 4.96$ & 0.76 & 114.25 & $54 \pm 10.42$ & 18.99 & 142.71 & $76.35 \pm 10.06$ \\
\hline $\begin{array}{c}\text { Locally processed beef } \\
\text { luncheon }(10)\end{array}$ & 5.22 & 75.5 & $30.63 \pm 8.28$ & 1.99 & 74.7 & $32.81 \pm 6.4$ & 18.99 & 131.7 & $63.43 \pm 12.46$ \\
\hline $\begin{array}{c}\text { Imported canned beef } \\
\text { luncheon }(5)\end{array}$ & 36.73 & 75.78 & $59.22 \pm 8.32$ & 2.99 & 59.56 & $21.78 \pm 11.16$ & 63.29 & 96.29 & $81 \pm 6.81$ \\
\hline $\begin{array}{c}\text { Locally processed canned } \\
\text { chicken sausage }(8)\end{array}$ & 7.46 & 47.08 & $27.54 \pm 4.54$ & 7.5 & 44.8 & $16.22 \pm 4.6$ & 22.06 & 91.88 & $43.77 \pm 7.96$ \\
\hline $\begin{array}{c}\text { Imported canned chicken } \\
\text { sausage (12) }\end{array}$ & 18.46 & 64.11 & $39.21 \pm 3.61$ & 2.65 & 93.78 & $29.07 \pm 7.36$ & 43.51 & 132.08 & $68.28 \pm 7.07$ \\
\hline $\begin{array}{c}\text { Imported canned chicken } \\
\text { luncheon (10) }\end{array}$ & 21.69 & 99.52 & $45.86 \pm 9.37$ & 12.65 & 149.76 & $49.55 \pm 14.55$ & 46.59 & 198.36 & $95.43 \pm 16.03$ \\
\hline $\begin{array}{c}\text { Locally processed chicken } \\
\text { luncheon (10) }\end{array}$ & 11.21 & 58.4 & $35.96 \pm 5.55$ & 1.06 & 99.81 & $37.92 \pm 9.05$ & 47.36 & 120.98 & $73.88 \pm 6.94$ \\
\hline
\end{tabular}

$\mathrm{n}=$ number of analysed samples $\quad$ Min. $=$ minimum $\quad$ Max. $=$ maximum $\quad$ S.E. $=$ standard error

N.B. The maxima for nitrite and nitrate limits in cured meat are $150 \& 250 \mathrm{mg} / \mathrm{kg}$ (ppm), respectively (JiménezColmenero and Solana, 2009) 


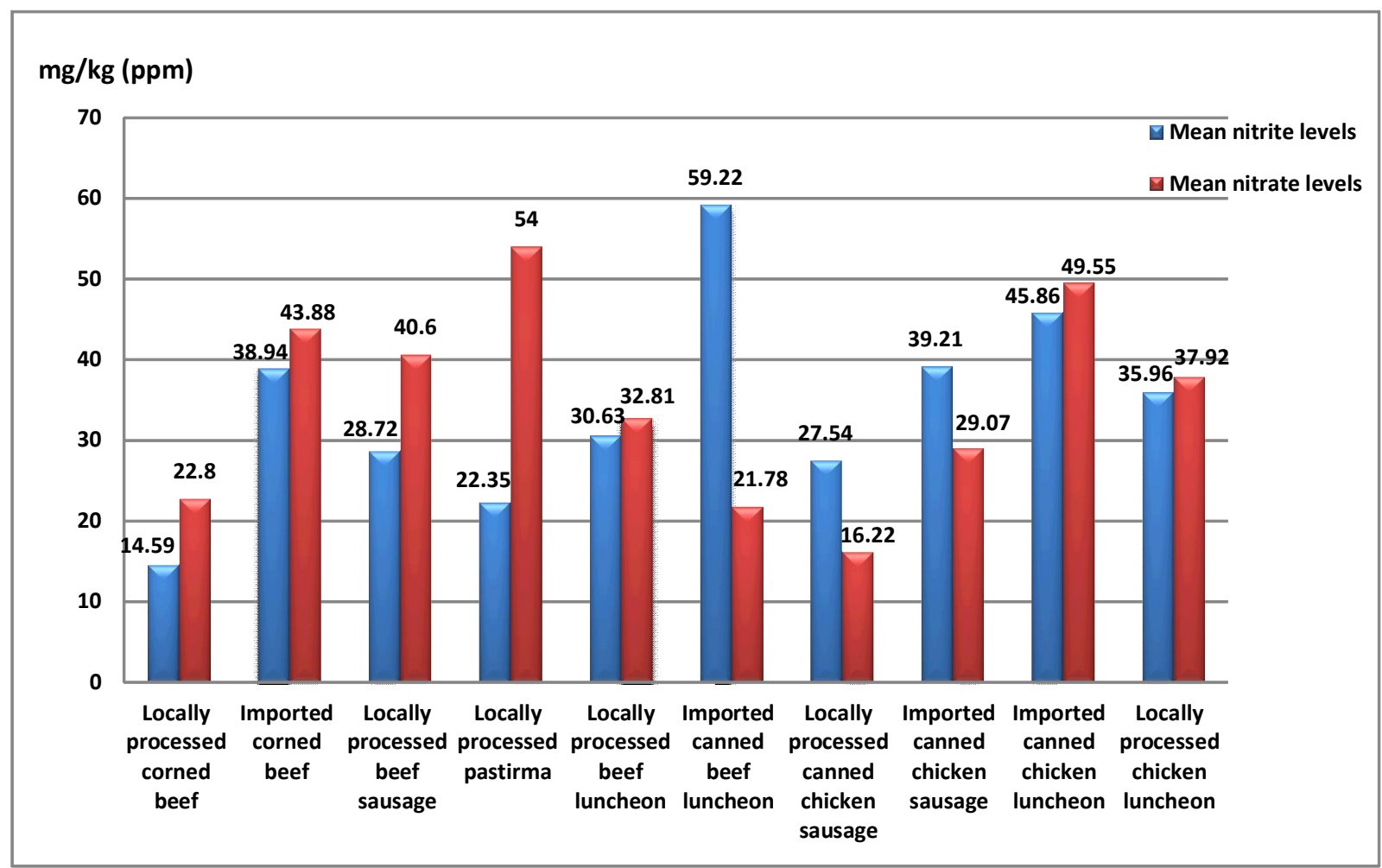

Fig (A) :Mean levels of nitrite and nitrate contents in cured meat products ( $\mathrm{n}=115$ for all samples)

N.B. The maxima for nitrite and nitrate limits in cured meat are $150 \& 250 \mathrm{mg} / \mathrm{kg}$ ( $\mathrm{ppm}$ ), respectively (JiménezColmenero and Solana, 2009).

\section{RESULTS\& DISCUSSION}

Data in both Table (1) and Figure (A) revealed presence of both nitrite and nitrate residues in all 115 cured meat samples $100 \%$ tested in this work. Concerning the tested locally processed corned beef samples the nitrite levels were detected as a mean \pm standard error $14.59 \pm 4.13$ with a range of 4.35 $-43 \mathrm{mg} / \mathrm{kg}$, whereas these findings for nitrate contents were $22.8 \pm 2.64$ and $13.91-40.58$ $\mathrm{mg} / \mathrm{kg}$ in the same samples, resulted in sum of nitrite and nitrate levels in such samples were $37.39 \pm 4.5$ and $23.91-62.2 \mathrm{mg} / \mathrm{kg}$, respectively. On the other hand both nitrite and nitrate levels were analyzed in imported corned beef samples by levels of $38.94 \pm 6.98$, 4.07 - 78.37, 43.88 \pm 6.62 and 12.32 - 102.5 $\mathrm{mg} / \mathrm{kg}$, consecutively, showed sum of nitrite and nitrate as $82.82 \pm 9.2$ and 30.77 - 141.9 $\mathrm{mg} / \mathrm{kg}$ in the same samples. The aforementioned data showed the contents of each of nitrite and nitrate in imported corned beef samples were approximately twice more than those found in locally processed corned beef samples. The type of meat used and the packaging technique affect nitrite contents in the finished products (Aksu et al., 2005), there were significant varieties between the nitrite and nitrate contents of cured meat products produced by different companies (Sancak et al., 2008). The meat product nitrite contents may probably be a sequence of microbial activity, this hold the view reported by Wolff 
and Wasserman (1972), who reported that the nitrite reducing bacteria may increase nitrite level in meat products by reduction of their nitrate content. By comparison, the range of nitrite levels in locally processed corned beef samples in agreement approximately with that estimated by Dennis et al. (1990) as $1.5-41.5$ $\mathrm{mg} / \mathrm{kg}$. Whereas higher mean nitrite levels were estimated by Nassif (1989) as 58.95 $\mathrm{mg} / \mathrm{kg}$. These variations may be due to freezing temperatures, which considered as an important reduction of residual nitrite in cured meat products such as corned beef. Residual nitrite contents were reduced almost half after $24 \mathrm{~h}$ of storage at $-18^{0} \mathrm{C}$ (Wootten et al., 1985), nitrite levels decreased by $50-65 \%$ during manufacture and thermal processing. On the other hand approximate equal mean nitrite value of imported corned beef samples obtained by El - Nawawi et al. (1998) as $49.76 \mathrm{mg} / \mathrm{kg}$ and Saad et al. (2013) as 42.3 $\mathrm{mg} / \mathrm{kg}$, while the similar equals mean value for nitrate contents estimated by Farag and Abd El - Fatah (2011) as $39.82 \mathrm{mg} / \mathrm{kg}$.

Regarding the analyzed locally processed beef sausage samples the nitrite levels were quantified as a mean \pm S.E. $28.72 \pm 4.34$ with a range of $6.65-82 \mathrm{mg} / \mathrm{kg}$, whereas similar findings for nitrate contents were $40.6 \pm 5.94$ and $8.93-113.01 \mathrm{mg} / \mathrm{kg}$ in the such samples, resulted in sum of nitrite and nitrate levels in the same samples were $69.33 \pm 7.92$ and $16.49-138.7 \mathrm{mg} / \mathrm{kg}$, respectively. On contrary, the equal mean values of nitrite quantities agreed with that reported by Honikel (2008) as $17.9 \mathrm{mg} / \mathrm{kg}$ and Pereira et al. (2011) as $35.6 \mathrm{mg} / \mathrm{kg}$, meanwhile higher mean nitrite values were detected by Samaha (1986) as $52.36 \mathrm{mg} / \mathrm{kg}$, while lower mean values were detected by Sancak et al. (2008) as $11.48 \mathrm{mg} / \mathrm{kg}$. The lower nitrite content in fresh sausage could be return to the reduced amount of nitrite and nitrate used in sausage production and, also other coloring ingredients that may be used to produce the attractive and desirable meat product color (Attall, 1997). Meanwhile approximate equal mean value for the sum of nitrite and nitrate in such samples was quantified by Shehata and Attia (1998) as $76.49 \mathrm{mg} / \mathrm{kg}$. The net changes in the nitrite and nitrate levels in sausage related to the balance between nitrite oxidation, reduction reactions, and nitrite binding to proteins, lipids and other meat components (Honikel, 2008).

Concerning the tested locally processed pastirma samples the nitrite levels were detected as a mean \pm standard error $22.35 \pm 4.96$ with a range of $2.03-69 \mathrm{mg} / \mathrm{kg}$, whereas similar findings for nitrate quantities were $54 \pm 10.42$ and $0.76-114.25 \mathrm{mg} / \mathrm{kg}$ in the same samples, resulted in sum of nitrite and nitrate levels in such samples were $76.35 \pm 10.06$ and 18.99 - $142.71 \mathrm{mg} / \mathrm{kg}$, successfully. By comparison, similar mean values for nitrite residues were detected by Soyutemiz and Ozenir (1996) as $15.95 \mathrm{mg} / \mathrm{kg}$ and Sancak et al. (2008) in Turkey as 12.53 $\mathrm{mg} / \mathrm{kg}$. The higher mean values were obtained by EI - Sayed (1998) as $314 \mathrm{mg} / \mathrm{kg}$, in Egypt, while lower mean values were reported by $\mathbf{E L}$ - Khateib et al. (1987) as $12 \mathrm{mg} / \mathrm{kg}$ in Turkish pastirma On the other hand approximate equal mean values for nitrate residues in the same samples were estimated by Sancak et al. (2008) as 58.54 ppm in Turkish pastirma and Farag and Abd El Fatah (2011) as $62.54 \mathrm{mg} / \mathrm{kg}$ in Egypt. Meanwhile higher mean values quantified by Soyutemiz and Ozenir (1996) as $80.02 \mathrm{mg} / \mathrm{kg}$ in Bursa. High nitrite levels in pastirma could be explain by that, the product is marketed as raw salt dry meat product without any exposure of heat treatment, also salt used at curing procedure may be contaminated with nitrite and nitrate salts, pastirma has longer curing times that, allowed nitrite dissipation and nitrate conversion to nitrite (USDA "United States Department of Agriculture" and FSIS "Food Safety and Inspection 
Service", 1995). In pastirma, the first added amounts of nitrite, and the production stages had significant effects on the residual nitrite contents.

Regarding the locally processed beef luncheon samples the nitrite levels were detected as a mean \pm standard error $30.63 \pm 8.28$ with a range of $5.22-75.5 \mathrm{mg} / \mathrm{kg}$, whereas these findings for nitrate contents were $32.81 \pm 6.4$ and $1.99-74.7 \mathrm{mg} / \mathrm{kg}$ in the same samples, resulted in sum of nitrite and nitrate levels in such samples were $63.43 \pm 12.46$ and $18.99-131.7 \mathrm{mg} / \mathrm{kg}$, respectively. On the other hand both nitrite and nitrate levels were analyzed in imported canned beef luncheon samples by levels of $59.22 \pm 8.32,36.73-75.78,21.78 \pm 11.16$ and $2.99-59.56 \mathrm{mg} / \mathrm{kg}$, successfully, showed sum of nitrite and nitrate as $81 \pm 6.81$ and 63.29 $96.29 \mathrm{mg} / \mathrm{kg}$ in such samples. The higher mean values were quantified - in Egypt - by El - Sayed (1998) as $204 \mathrm{mg} / \mathrm{kg}$, while lower value for the sum of nitrite and nitrate contents was detected by Hna et al. (1972) as $39 \mathrm{mg} / \mathrm{kg}$ at the beginning of storage and determined that $+5{ }^{0} \mathrm{C}-$ cold storage. The largest decline is obtained during the manufacturing up to the end of the heating procedure, cooking time and duration of storage affected nitrite residues (Food Standards Agency, 1998).

On the other hand, the similar mean nitrite values of imported canned beef luncheon were supported by that estimated by Nassif (1989) as $32.19 \mathrm{mg} / \mathrm{kg}$ and El Nawawi et al. (1998) as $45.5 \mathrm{mg} / \mathrm{kg}$. Meanwhile higher mean nitrite value was estimated by Farag and Abd El - Fatah (2011) as $159.96 \mathrm{mg} / \mathrm{kg}$, but lower mean value was obtained by Abd El - Daym (2005) as $3.69 \mathrm{mg} / \mathrm{kg}$. This variation due to nitrite and nitrate residues were lower during the storage time (Dogruer and Guner, 2005), there were variations in the similar meat products results produced by different companies (Sancak et al., 2008). ). And also the approximate equal mean value for nitrate in the same samples found by Farag and Abd El - Fatah (2011) as $28.52 \mathrm{mg} / \mathrm{kg}$.

Regarding the tested locally processed canned chicken sausage samples the nitrite quantities were quantified as a mean \pm standard error $27.54 \pm 4.54$ with a range of 7.46 $-47.08 \mathrm{mg} / \mathrm{kg}$, whereas these findings for nitrate quantities were $16.22 \pm 4.6$ and 7.5 $44.8 \mathrm{mg} / \mathrm{kg}$ in such samples, resulted in sum of nitrite and nitrate levels in the same samples were $43.77 \pm 7.96$ and $22.06-91.88 \mathrm{mg} / \mathrm{kg}$, respectively. On the other hand both nitrite and nitrate levels were estimated in imported canned chicken sausage samples by levels of $39.21 \pm 3.61,18.46-64.11,29.07 \pm 7.36$ and $2.65-93.78 \mathrm{mg} / \mathrm{kg}$, consecutively, showed sum of nitrite and nitrate as $68.28 \pm 7.07$ and $43.51-132.08 \mathrm{mg} / \mathrm{kg}$ in the same samples. The previous data showed the contents of each of nitrite and nitrate in imported canned chicken sausage samples more than those found in locally processed canned chicken sausage. These results in nitrite contents of locally processed canned chicken sausage were supported by that obtained by and EI Nawawi et al. (1998) as $30.9 \mathrm{mg} / \mathrm{kg}$, while lower mean value was detected by Abd El Daym (2005) as $9.7 \mathrm{mg} / \mathrm{kg}$. These mean value results in nitrite contents of imported canned chicken sausage were supported by that obtained by Hassan (1997) as $42.91 \mathrm{mg} / \mathrm{kg}$ (in canned meat) and El - Nawawi et al. (1998) as $30.9 \mathrm{mg} / \mathrm{kg}$ (in 40 canned meat samples). Where increasing the quality of meat products, reducing the nitrite contents over time, it is best that they are at least consumed after 7-10 days from production time. (Khodadady et al., 2012).

Concerning the analyzed locally processed chicken luncheon samples the nitrite levels were detected as a mean \pm standard error $35.96 \pm 5.55$ with a range of $11.21-58.4$ 
$\mathrm{mg} / \mathrm{kg}$, whereas these findings for nitrate contents were $37.92 \pm 9.05$ and 1.06 - 99.81 $\mathrm{mg} / \mathrm{kg}$ in the same samples, resulted in sum of nitrite and nitrate levels in such samples were $73.88 \pm 6.94$ and 47.36 - $120.98 \mathrm{mg} / \mathrm{kg}$, respectively. On the other hand both nitrite and nitrate levels were quantified in imported canned chicken luncheon samples by levels of $45.86 \pm 9.37,21.69-99.52,49.55 \pm 14.55$ and 12.65 - $149.76 \mathrm{mg} / \mathrm{kg}$, successfully, showed sum of nitrite and nitrate as $95.43 \pm 16.03$ and $46.59-198.36 \mathrm{mg} / \mathrm{kg}$ in the same samples. The aforementioned data showed the contents of each of nitrite and nitrate in imported canned chicken luncheon samples more than those found in locally processed chicken luncheon samples, this may be due to the longer storage period in imported canned chicken luncheon, cure accelerators, variations in packaging method and type (Pegg and Shahidi, 2000). On contrary, approximate equal mean values of nitrite levels in locally processed chicken luncheon were supported by those obtained by Sen and Baddoo (1997) as $28 \mathrm{mg} / \mathrm{kg}$, as $31 \mathrm{mg} / \mathrm{kg}$ in 1993-1995 and as 28 $\mathrm{mg} / \mathrm{kg}$ in 1996 (in Canadian cured meat products), meanwhile the lower mean values were estimated by White (1975) as 10 ppm (in cured meat samples), the nitrite content in the finished cured meat products was usually nearly $10-20 \%$ of the first added amount (Cassens, 1995).

On the other hand the nearly similar range of nitrite contents in imported canned chicken luncheon was estimated Bernal Jorres et al. (1987) by 23.76-105.4 ppm, in Cuba (in some cured meat products) and nearly similar mean values was obtained by Hassan (1997) as $42.91 \mathrm{mg} / \mathrm{kg}$ (in canned meat).

The decline in the residual nitrite contents obtained in this work due to oxidation to nitrate, beside its chemical conversion to nitric oxide, which is highly reactive and binds to myoglobin and other meat components. Meanwhile, an excess of nitrite quantities would cause feedback inhibition of nitrate reductase, and also causing higher nitrate levels (Stahnke, 1995).

\section{CONCLUSION AND RECOMMENDATIONS}

In spite of none of the surveyed cured meat products samples possessed nitrite or nitrate level more than their limits recommended by (Jiménez-Colmenero and Solana, 2009) as 150 \& $250 \mathrm{mg} / \mathrm{kg}$, respectively, the future quantitative surveillance for both nitrite \& nitrate residues in Egypt must be continuous for ensuring the safety and the good keeping quality for these products.

\section{REFERENCES}

Abd El - Daym, W. F. A. (2005): Food poisoning agents in some meat products. Ph. D. V. M. Sc. Thesis (Meat Hygiene), Fac. Vet. Med., Zagazig Univ., Egypt.

Aksu M. I. and Oskerman H. W. (2005): Effect of modified atmosphere packaging and storage temperature on the residual nitrite of sliced pastirma, dry meat products, produced from fresh meat and frozen/thawed meat. Food Chemistry. 93 (2): $237-242$.

Attall, O. A. (1997): Impact of component of pastirma on its organoleptic, bacteriological and chemical status. M. V. M. Sc. Thesis (Meat Hygiene) Fac. Vet. Med., Cairo Univ., Egypt. 
Bernal-Jorres E., Valerna-Diaz M., Morfa O. and Garcia-Roche M. (1987): Nitrite content of various uncanned sausages manufactured in Cuba. Revista Cubana de Higieney Epidem., 25 (3): 253.

Cassens, R. G. (1995): Use of sodium nitrite in cured meat today. Food Technol., 49 (7): $72-79,115$.

Dennis M. J., Key P.E., Papworth T., Pointer M. and Massey R. C. (1990): The determination of nitrate and nitrite in cured meat by HPLC / UV. Food additives and contaminants, 7 (4): 455 $-461$.

Dogruer Y. and Guner A. (2005): Effect of using sodium and potassium nitrate on degrading and residue level of nitrate and nitrite contents of pastirma during the storage period. Acta Alimentaria, 34 (2) 141-144.

EL - Khateib T., Schmidt T. and Leistner U. L. (1987): Microbiological stability of Turkish pastirma. Fleischwirtsch, 67: 101-105.

EI - Nawawi F. A., EI - Sherif A. and El Khawas K. M. (1998): Chemical analysis of canned meat products in relation to public health aspects. Vet. Med. J., Giza, 46(4): 355-362.

El - Sayed, H. (1998): Adulteration of some local processed meat products. Mansoura J. of Agriulture Science, 23 (5): 2023-2031.

Farag H. EL - S. M. and Abd EI - Fatah N. R. M. (2011): Assessment of nitrate and sorbic acid salts levels in some meat products and their public health significance. Assiut Veterinary Medical J., 57 (129): 1-22.

Food Standards Agency (1998): Total diet study, nitrate and nitrite. Food
Surveillance information sheet No. (163), London.

Hassan, M. A. (1997): Meat additive profiles of Egyptian meat products with relation to public health. J. Fac. Vet. Med., 13: 821-828.

Hna L. H., Webb N. B., Moncol N. D. and Adams A. T. (1972): Changes in residual nitrite in sausage and luncheon meat products during storage. J. Milk Food Technol., 36 (10): 515-519.

Honikel, K. O. (2008): The use and control of nitrate and nitrite for the processing of meat products. Meat Science, 78: 6876.

Hyytia E., Eerola S., Hielm S. and Korkeala H. (1997):Sodium nitrite and potassium nitrate in control of non proteolytic Clostridium botulinum outgrowth and toxigenesis in vacuumpacked cold-smoked rainbow trout. International J. of Food Microbiology, 37: $63-72$.

Jiménez-Colmenero F. and Solana J. B. (2009): Additives: Preservatives (chapter 5). In: Handbook of processed meat and poultry analysis, by Nollet L. M. L. and Toldra F. (editors). CRC press, Taylor\& Francis Group, LLC. Pp. 91-108.

Khodadady M., Shahryari T., Dorri H., Sharifzadah G. R. and Ziyazade A. (2012): Evaluation of nitrite in meat products (sausages and salami) are distributed in Birjand in 2012, Pelagia Research Library, European J. of Experimental Biology, 2 (6):21202124.

Nassif, M. R. (1989): Quality control of canned meat. M. V. M. Sc. Thesis (Meat Hygiene), Fac. Vet. Med. Alex. Univ., Egypt. 
Pegg R. B. and Shahidi F. (2000): Nitrite curing of meat. Trumbull, Conn.: Food and Nutrition Press, Inc.:7-66.

Pereira E. A., Petruci J. F. S. and Cardoso A. A. (2011): Determination of nitrite and nitrate in Brazilian meat using High Shear Homogenization. Food Anal. Methods, 5:637- 642.

Saad S. M., Edris A. M., Ibrahim H. M. and Hassanin F. S. (2013): Studies on nitrites as a chemical preservative in some meat products. Benha Veterinary Medical J. 24 (1):298-308.

Samaha, I. (1986): Histological and microbial evaluation of some meat products. M.V. M. Sc. Thesis (Meat Hygiene), Fac. Vet. Med., Alexandria Univ., Egypt.

Sancak Y. C., Ekici K. and Isleyici $O$. (2008): Nitrate and nitrite residue levels in fermented Turkish sausage and pastirma. YYU. Vet. Fak. Derg, 19 (1):41-45.

Sen N. and Baddoo P. A. (1997): Trends in the levels of residual nitrite in Canadian cured meat. J. of Agriculture and Food Chemistry. 45(12): 4714 4718 .

Sen N. P. and Donaldson B. (1978): Improved colorimetric method for determining nitrate and nitrite in food. J. Assoc. off. Anal. Chem., 61(6): 13891395.

Shehata H. A. and Attia E. A. (1998): Effect of some additives on the quality of low fat cooked emulsion sausage of beef. Tura, Cairo/ Egypt. Food Technology Institute. A.R.C, Giza/Egypt. http://www.eulc.edu.eg/.
Soyutemiz G. E. and Ozenir A. (1996): Determination of residual nitrate and nitrite contents of dry fermented sausage, salami, sausage and pastirma consumed in Bursa. GIDA, 21(6): 471476.

Stahnke, L. H. (1995): Dried sausages fermented with Staphylococcus xylosus at different temperatures and with different ingredient levels - Part II. Volatile components. Meat Science, 41:193-209.

USDA "United States Department of Agriculture" and FSIS "Food Service and Inspection Service" (1995): Focus on sausages. Washington DC: United States Department of Agriculture. Available from:

http://www.fsis.Usda.gov/oa/pubs/saus ages.htm. Accessed 2001, Sep 30.

White, J. W. Jr. (1975): Relative significance of dietary sources of nitrate and nitrite. J. Agric. Food Chem., 23:886-891.

Wood E. D., Armstrong F. A. J. and Richards F. A. (1967): Determination of nitrate in sea water by cadmium copper reduction to nitrite. J. Mar. Biol. Assoc. U.K. 47: 23.

Wolff I. A. and Wasserman A. E. (1972): Nitrates; nitrites and nitrosamines, Science 177: 15-19.

Wootton M., Kok S. H. and Buckle K. A. (1985): Determination of nitrite and nitrate levels in meat and vegetable products by HPLC. J. Sci. Food Agric. 36: 297-304. 


\title{
الملخص العربي \\ التقدير الكمي للنيتريت والنترات بواسطة مقياس الطيف الضوئي في \\ اللحوم المعالجة المصنعة
}

\author{
* م/زينب خليل مهدي العوامري \\ أ. د / محمد محمد محمد إبراهيه الجزار* \\ ط.* ب بهلة حمادة مجد خليل \\ *** د حسن علي محمد معروف

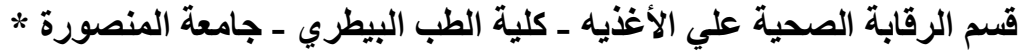

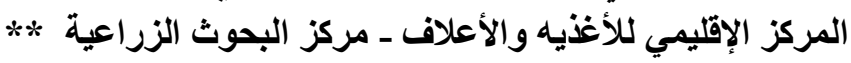

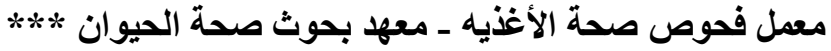

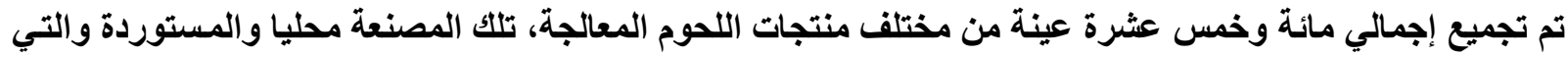

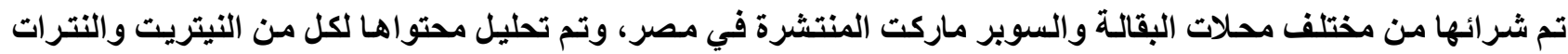

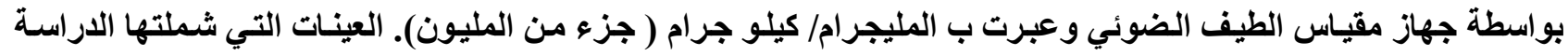
تكونت من خمس وعثرون من عينات اللحوم البقرية المعلبة (تسعة مصنعة محليا بالإضافة إلى ستة عشرة المستوردة منها)، عشرون من سجق اللحم البقري المصنع محليا، خمس عشرة من البسطرمة المصنعة محليا، عشر من لانشون اللحم البقري

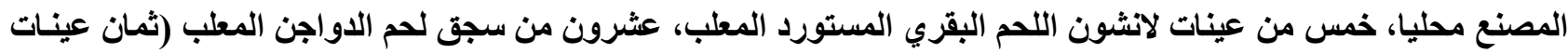

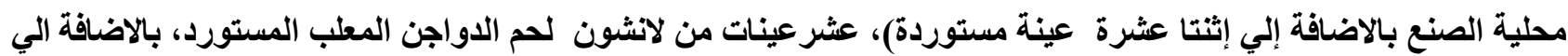

عشرمن عينات لانشون لحم الدواجن المصنع محليا.

حدد مقياس التحليل الطيفي الضوئي النطاق ( الحد الأدني ـ الحد الأقصي) والقيمة المتوسطة 土 الخطأ العياري لمحتوي

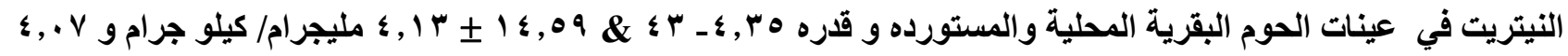

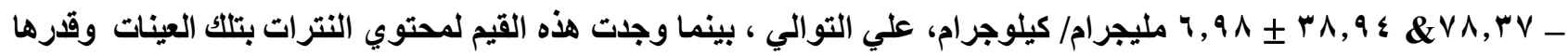

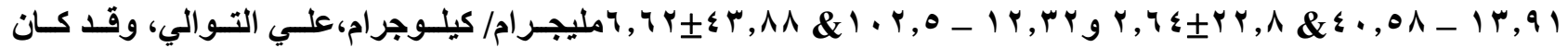

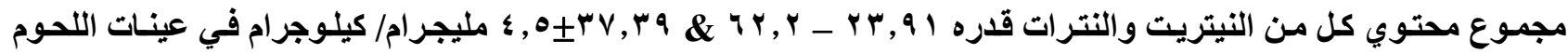

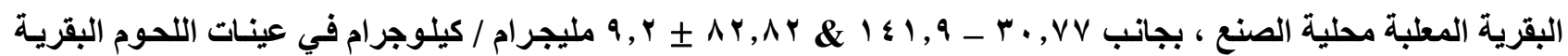
المعلبة المستوردة، علي التوالي.

أسفرت تقنية التحليل المذكوره سابقا عن الحد الادني ، الحد الاقصي، ومتوسط القيمه 土 الخطأ العياري لمحتوي النيتريت

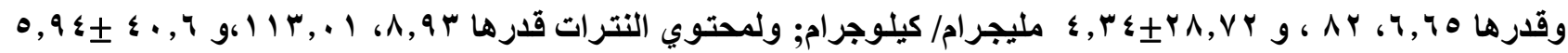

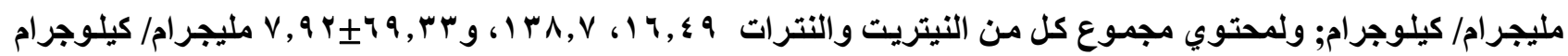

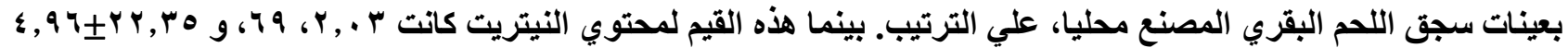

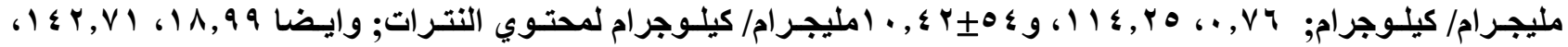

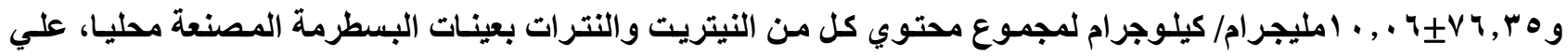
التوالي. 
وق وجدت الكميات الأقل لكل من النيتريت، النترات،ومجموع كل منهمـا بانسجة عينـات كل من لانشون اللحم البقري

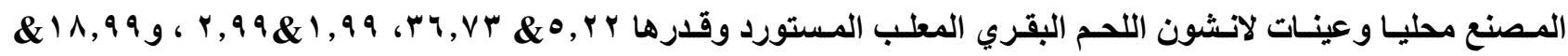

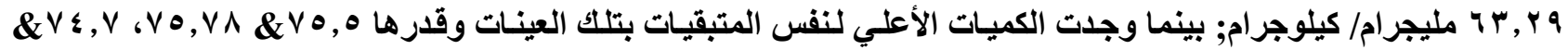

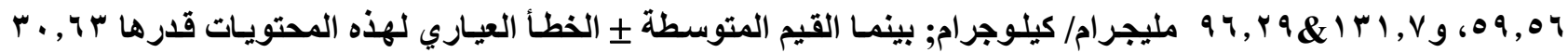
ع ع علي الترتيب.

وكما كثفت أنسجة عينات سجق لحم الدواجن المعلب المصنع محليا عن مدي محتوي النيتريت،النترات،ومجموع كوع كل

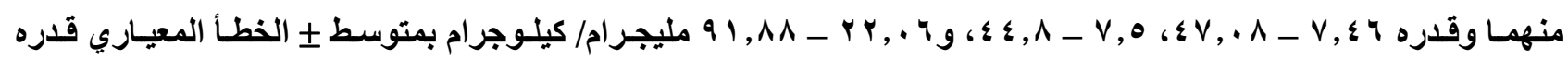

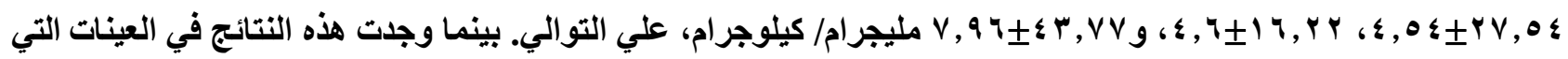

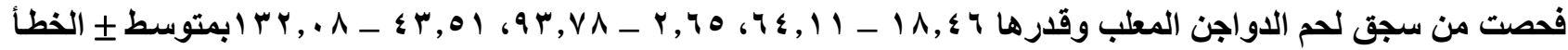

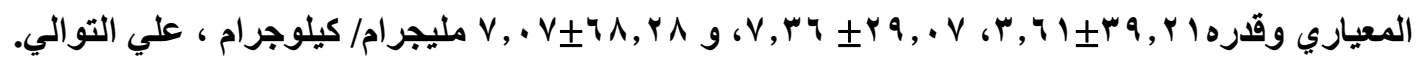
وقد أسفرت نتائج التحليل الطيفي لعينات لانثون لحم الدواجن المعلب المستورد عن القيم المتوسطة 土ـ الخطأ المعياري

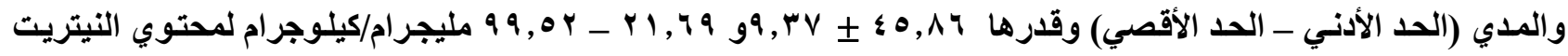

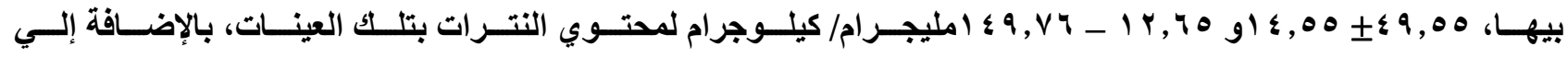

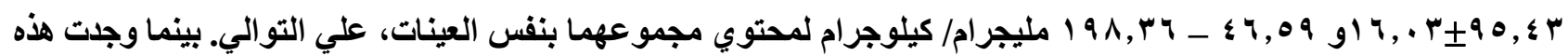

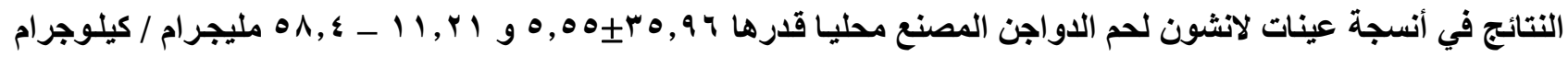

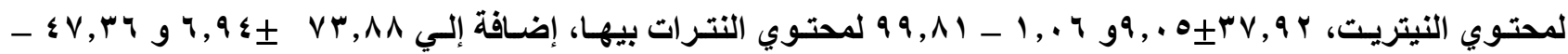

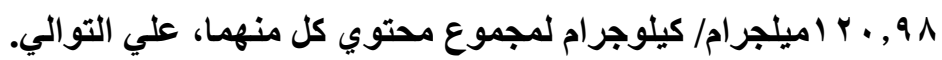

إستعراضا للنتائج السابقة التي تم الحصول عليها، لا شئ من عينات اللحوم المعالجة المحفوظة بإضافة كل من النيتريت

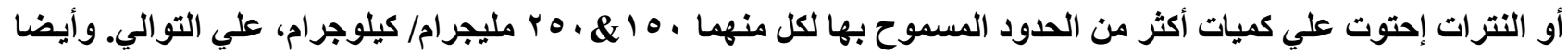

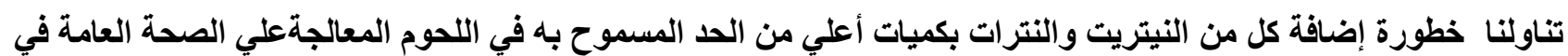
مصر في هذه الأطروحة. 